\title{
GEOSPATIAL APPROACH FOR QUANTITATIVE DRAINAGE MORPHOMETRIC ANALYSIS OF VARUNA RIVER BASIN, INDIA
}

\author{
PRAVEEN KUMAR RAI ${ }^{1 *}$, PrAFULl SINGH ${ }^{1}$, VARUN NARAYAN MiSHRA ${ }^{2}$, \\ ANISHA SINGH ${ }^{2}$, BHARTENDU SAJAN $^{2}$, ARJUN PRATAP SHAHI $^{3}$ \\ ${ }^{1}$ Amity Institute of Geo-Informatics and Remote Sensing, Amity University, Noida, U.P., \\ India \\ ${ }^{2}$ Centre for Climate Change and Water Research, Suresh Gyan Vihar University, Jaipur, \\ India \\ ${ }^{3}$ Department of Remote Sensing, Birla Institute of Technology, Mesra, Ranchi, India \\ *Corresponding author email: rai.vns82@gmail.com
}

Received: $1^{\text {st }}$ March 2019, Accepted: $13^{\text {th }}$ April 2019

\begin{abstract}
An assessment of Varuna river basin of India was performed to study the various drainage parameters in GIS platform. The delineation of drainage network is possible either physically from topographic sheets or with the help data of Digital Elevation Model (DEM) by methods for calculation techniques. Extraction of the basin and sub-basins, stream network has been produced to evaluate the drainage characteristics in the study zone. The entire Varuna river basin has been subdivided into 3 sub-watersheds and 41 morphometric parameters have been computed under four broad categories i.e. drainage network, basin geometry, drainage texture, and relief characteristics. The morphometric analysis has been performed and different parameters have been correlated with each other to understand their underlying connection and their role over the basin hydro geomorphology. The study discloses different types of morphometric analysis and how they influence the soil and topography of the basin. The investigation and estimation of basin morphometry and relief parameters in GIS will be of massive utility in catchment area advancement, understanding the watershed for natural resource evaluation, planning and administration at any scale. The outcomes thus generated equip us with significant knowledge and may also provide an input that are essential in decision making for watershed planning and drainage development of the watershed.
\end{abstract}

Keywords: River basin, morphometry, Varuna river, DEM, GIS, watershed

\section{INTRODUCTION}

Water is a characteristic asset and an essential human need. It gives life and vocation. It is likewise an essential requirement for any arrangement and improvement. Due to growth in population, water irrigation system and industrialization, the interest for water has gone to an expansive degree. So in order to achieve sustainability, watershed management is necessary and plays an important part of it and study of watershed morphometry is an important aspect in its management (Javed et. al., 2009; Rai et. al., 2017a \& 2017b, Prakash et.al., 2019). 
Rai, P.K. \& Singh, P. et al.: Geospatial approach for quantitative drainage morphometric analysis of Varuna river basin, India

A thorough analysis of the morphometry of a watershed is helpful in understanding the impact of stream morphometry. Morphometry is the measurement and mathematical analysis of the configuration of the Earth's surface, shape and dimension of its landforms (Clarke, 1966). It is the measurement and mathematical analysis of the configuration of the earth's surface, shape and dimension of its landforms (Agarwal, 1998; Obi Reddy et al., 2002; Rai et. al., 2014; Rai et. al., 2017a \& 2017b; Rai et. al., 2018). Morphometric analysis is one of the most important tool and technique to determine and evaluate the drainage basin responses to climate change, drainage characteristics (Mesa, 2006; Rais and Javed 2014), flash flood hazard (Angillieri, 2008; Perucca \& Angilieri, 2010), and hydrologic processes (Eze \& Efiong, 2010). There is a strong need to include the geomorphological parameters of the river basin in flood analysis as these parameters govern the hydrological response of the river basin (Sinha \& Jain, 1998).

Analysis of the stream morphometry using remote sensing technique has developed as a powerful tool in recent past. Remote sensing has the capacity of getting brief perspective of extensive and remote zones and it is very useful in analysing the morphometry of the any drainage system. Remote sensing and G1S techniques have developed as an effective tool for the watershed development programmes. Analysis of the morphometry is applied to prioritize watersheds and it then helps in understanding hydrological characteristics of the watershed like structure, relief of the watershed, stream networks, platform and topology (Javed et al., 2011; Khanday \& Javed 2016; Rai et al., 2017a \& 2017b; Pande et.al., 2018).

Morphometric analysis requires measurement of linear features, areal aspects, gradient of Channel network and contributing ground slopes of the drainage basin. Using watershed as a basic unit in morphometrical analysis is the most logical choice, and remote sensing technique has emerged as a powerful tool in recent years, which plays a vital role in understanding the Hydro-geological behaviour of drainage basin and expresses the prevailing climate, geology, geomorphology and structure. (Nautiyal, 1994)

Applications of geographical information system (GIS) techniques are much efficient, time-saving and suitable for spatial planning. GIS can handle complex issues and large databases for manipulation and retrieval. The use of computer has made GIS automated and today the technique is not only capable of handling large datasets, but can also solve many complex issues besides facilitating retrieval and querying of data. (Kumar et al., 2016)

The present study draws connection between surface morphometry and subsurface geology of a drainage basin to prepare effective information as a part of basin management. So the aim of the present research is to interrogate all the morphometric characteristics of Varuna River basin and to recognize the impact of the basic topography on the morphometric characteristics.

\section{STUDY AREA}

The name "Varanasi" itself is described to be coming from the name of the river Varuna. The study area lies between the latitudes $25^{\circ} 21^{\prime} 46.89^{\prime \prime} \mathrm{N}$ to $25^{\circ} 21^{\prime} 44.88^{\prime \prime} \mathrm{N}$ and $82^{\circ} 55^{\prime} 22.708^{\prime \prime}$ E to $82^{\circ} 58^{\prime} 28.33^{\prime \prime}$ E longitude which designate whole of the Varuna River basin with three watersheds. The Varuna River rises at $25^{\circ} 27^{\prime} \mathrm{N}$ to $82^{\circ} 18^{\prime} \mathrm{E}$ near Bhadohi, flows east-to-southeast for some $100 \mathrm{~km}$, and joins the Ganges river at $25^{\circ} 19^{\prime} 46^{\prime \prime} \mathrm{N}$ to $83^{\circ} 02^{\prime} 40^{\prime \prime} \mathrm{E}$ downstream Varanasi. The total area of the Varun river basin is $3445.14 \mathrm{sq}$. kms. The Varuna River is the influent or tributary of the Ganga River that currently flows from west towards east direction before it finally joins the Ganga at the place named Mohan Sarai. Location of the study area is shown in the Fig.1. 


\section{SILENT FEATURE OF THE VARUN RIVER BASIN}

\section{Geology}

The river basin has unconsolidated sediments from a sequence of clays to sands of different grades. Geologically, the Varuna River basin belongs to Indo-Gangetic plain which is underlain by quaternary alluvial sediments of Pleistocene to recent age. Some of the part of the basin has nodular calcareous concretions (kankars) that are at times intercalated among the sands and form potential aquifers at various depths. Shallow aquifers occur principally in clay, kankar and meander river deposits. Basin has deep aquifers which occur in thick sand layers and have good potentials (Raju et al., 2009).

\section{Geomorphology}

The lower Varuna River basin in Varanasi district has a highly productive agricultural area which is situated in the central Ganga plain and is also one of the fast developing urban areas in the state. The agricultural and urbanization activities impact a lot the groundwater quality of the study area. The river basin is underlain by quaternary alluvial sediments consisting of clay, silt, sand and gravel of various grades. Based on the total dissolved solids, two groundwater samples were considered unsuitable for drinking purpose, but all samples were found useful for irrigation (Raju et al., 2009).

\section{Fig. 1: Location of the Study Area}
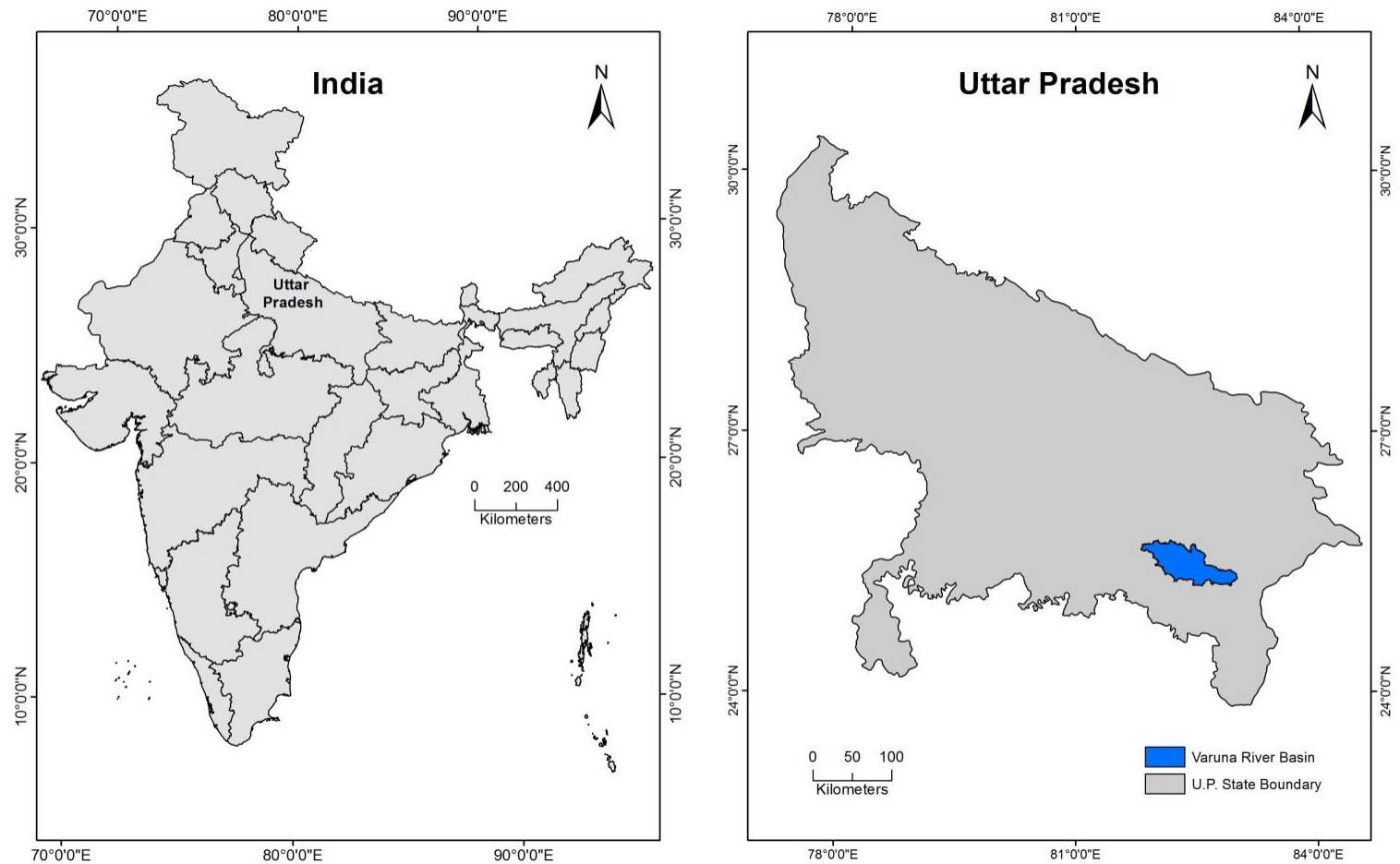
Rai, P.K. \& Singh, P. et al.: Geospatial approach for quantitative drainage morphometric analysis of Varuna river basin, India

\section{Hydrogeology}

Hydrogeological investigation is based on understanding the nature of aquifers and their mode of occurrence. The availability of groundwater in alluvial zones is controlled by the thickness of sand and clay-zones present over there. Near surface groundwater occur under unconfined aquifer condition, while deeper aquifers occur in semi-confined to confined aquifer conditions. In the Varuna River basin aquifer level occurs to be generally in semi-confined and confined conditions. Rainfall is the basic source for the recharge of groundwater in the basin. The water level shows deteriorating trend in some parts of the study area because of fast urbanization and intensive pumping. The average hydraulic gradient is $0.35 \mathrm{~m} / \mathrm{km}$ which indicates porous nature of near surface formations of the area (Pandey, 1993; Raju et al., 2009).

\section{DATA USED \& METHODOLOGY}

The measurements and mathematical investigation of the configuration of the earth's surface and of the shape and dimensions of its landform deliver the basis for the study of maps for a geomorphological feature (Bates \& Jackson, 1980). The area, altitude, volume, slope, profile and texture of landforms are the principal parameters to be studied of a basin under morphometric study. Dury (1952) used different methods for landform analysis, which could be classified in different ways and his results were presented in the form of graphs, maps and statistical indices (Pareta et al., 2011; Rai et al., 2014). The morphometric analysis of the Varuna basin and its three watersheds was carried out individually using the ASTER-DEM with $30 \mathrm{~m}$ spatial resolution in the GIS platform (Fig.2).

Delineation of the drainage network and assigning the stream order from Survey of India (SOI) topographical map for a large river basin is a tiresome work. To overcome this problem, The Arc hydro approach is used for drainage delineation which is more dependable tool when matched to a manual method (Rai et al., 2017a). A geoprocessing model was used for evaluating the morphometric parameters. The Varun river basin boundary and its main sub watershed were delineated from ASTER DEM data using ArcGIS spatial analyst tool. The length of the streams and area of the watershed were calculated and stream order was generated using Strahler (1953) system in Arc hydro tool.

The linear aspects were studied using the methods of Horton (1945); Strahler (1953); Chorley (1957), the areal aspects using those of Schumm (1956); Strahler (1956, 1968); Miller (1953); and Horton (1932), and for the relief aspects the techniques of Horton (1945); Broscoe (1959); Melton (1957); Schumm (1956); Strahler (1952); Pareta \& Pareta (2012) were employed; (Rai et al., 2014; Magesh et al., 2013 and 2014). The average slope analysis of the whole watershed area was performed using the Wentworth (1930) method (Pareta et al., 2011). The Drainage density and the frequency distribution analysis of the watershed area were also carried out (Rai et al., 2014). All the 3 watersheds of the Varuna basin were delineated for the detailed analysis of morphometry in this study. 
Fig. 2: ASTER-DEM of the Varun River Basin

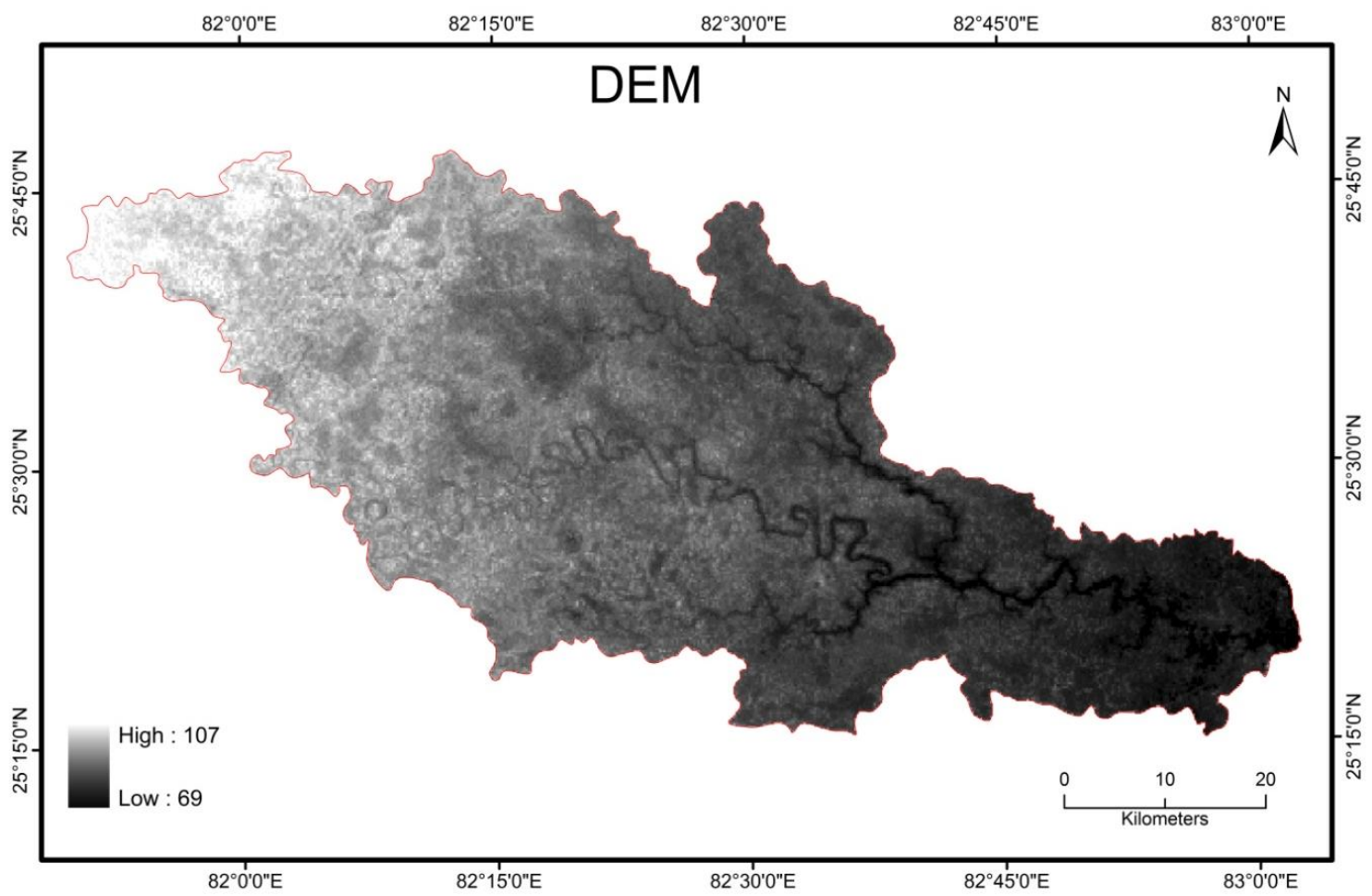

\section{RESULTS AND DISCUSSION}

Morphometry is defined as the mathematical measurement of the shape. Morphometric studies in the field of hydrology were first performed by Horton and Strahler in the 1940s and 1950s. The main purpose of this study aims to discover holistic stream properties by the measurement and computation of its various attributes. The morphometric parameters of Varuna river basin and its three watersheds were studied and the outcomes are given below (Table 1.1 to 1.4). A comparative quantitative morphometric characteristic of drainage network, basin geometry, drainage texture and relief aspect of the Varuna basin are given in the Table 2, 3, 4 and 5.Plate 1 (a-c) show the Varuna river and its surrounding land use and (d) a dry stream of Varun river basin. 
Rai, P.K. \& Singh, P. et al.: Geospatial approach for quantitative drainage morphometric analysis of Varuna river basin, India

Table 1: Morphometric Parameters Calculation of Varuna Main River basin

\begin{tabular}{|c|c|c|c|c|c|c|c|c|c|c|c|}
\hline $\begin{array}{c}\text { Stream } \\
\text { Property }\end{array}$ & U & Nu & Lu & Mean & Sd & Lsm & RL & Rb & Ndu & Rdb & R \\
\hline \multirow{5}{*}{} & 1 & 226 & 587.04 & 2.62 & 2.31 & 2.60 & & 4.52 & 155.00 & 3.10 & 1.42 \\
\cline { 2 - 13 } & 2 & 50 & 317.98 & 3.14 & 2.63 & 6.36 & 0.54 & 4.17 & 28.00 & 2.33 & 1.83 \\
\cline { 2 - 13 } & 3 & 12 & 150.67 & 3.50 & 2.63 & 12.56 & 0.47 & 4.00 & 11.00 & 3.67 & 0.33 \\
\cline { 2 - 12 } & 4 & 3 & 175.01 & 3.01 & 3.27 & 58.34 & 1.16 & 3.00 & 3.00 & 3.00 & 0.00 \\
\cline { 2 - 12 } & 5 & 1 & 51.44 & 2.85 & 1.72 & 51.44 & 0.29 & - & - & - & - \\
\hline Total & - & 292 & 1282.14 & 15.12 & 12.56 & 131.29 & 2.47 & 3.92 & - & 12.10 & 3.59 \\
\hline Mean & - & - & - & 3.02 & 2.51 & 26.26 & 0.62 & - & - & 3.03 & 0.90 \\
\hline
\end{tabular}

$\mathbf{U}=$ Stream order, $\mathbf{N u}=$ No. of stream segments, $\mathbf{L u}=$ Length, $\mathbf{S D}=$ Standard Deviation, $\mathbf{L s m}=$ Mean stream length $(\mathrm{Lsm})=\mathrm{Lu} / \mathrm{Nu}, \mathbf{R L}=$ Stream length ratio $(\mathrm{RL})=\mathrm{Lu} / \mathrm{Lu}-1, \mathbf{R} \mathbf{b}=$ Bifurcation ratio $(\mathrm{Rb})=$

$\mathrm{Nu} / \mathrm{Nu}+1, \mathbf{N d u}=\mathrm{No}$. Of stream of $\mathbf{u}$ order which flowing in $\mathbf{u}+1$ order, $\mathbf{R d b}=$ Direct bifurcation ratio

$(\mathrm{Rdb})=\mathrm{Ndu} / \mathrm{Nu}+1, \mathbf{R}=$ Bifurcation Index $(\mathrm{R})=\mathrm{Rb}-\mathrm{Rdb}$

Table 2: Morphometric Parameters Calculation of Varuna Watersheds 1, 2, and 3

\begin{tabular}{|c|c|c|c|c|c|c|c|c|c|c|c|c|}
\hline \multirow{7}{*}{ 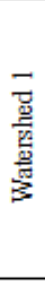 } & Stream Property & $\mathrm{U}$ & $\mathrm{Nu}$ & Lu & Mean & Sd & Lsm & RL & $\mathrm{Rb}$ & Ndu & Rdb & $\mathbf{R}$ \\
\hline & & 1 & 111 & 262.46 & 2.67 & 2.44 & 2.36 & - & 4.27 & 86.00 & 3.31 & 0.96 \\
\hline & & 2 & 26 & 144.30 & 3.00 & 2.32 & 5.55 & 0.55 & 3.71 & 18.00 & 2.57 & 1.14 \\
\hline & & 3 & 7 & 66.55 & 3.50 & 2.52 & 9.51 & 0.46 & 7.00 & 7.00 & 7.00 & 0.00 \\
\hline & & 4 & 1 & 90.87 & 2.75 & 3.45 & 90.87 & 1.37 & - & - & - & - \\
\hline & Total & - & 145 & 564.18 & 11.92 & 10.73 & 108.29 & 2.38 & 4.99 & - & 12.88 & 2.10 \\
\hline & Mean & - & - & - & 2.98 & 2.68 & 27.07 & 0.79 & - & - & 3.22 & 0.53 \\
\hline & & & & & & & & & & & & \\
\hline \multirow{6}{*}{ 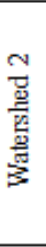 } & & 1 & 45 & 92.61 & 2.31 & 1.79 & 2.06 & - & 6.43 & 20.00 & 2.86 & 3.57 \\
\hline & & 2 & 7 & 41.23 & 2.94 & 2.93 & 5.89 & 0.45 & 3.50 & 5.00 & 2.50 & 1.00 \\
\hline & & 3 & 2 & 49.55 & 3.50 & 3.35 & 24.78 & 1.20 & 2.00 & 2.00 & 2.00 & 0.00 \\
\hline & & 4 & 1 & 57.34 & 4.09 & 3.64 & 57.34 & 1.16 & - & - & - & - \\
\hline & Total & - & 55 & 240.73 & 12.84 & 11.71 & 90.06 & 2.80 & 2.98 & - & 7.36 & 4.57 \\
\hline & Mean & - & - & - & 2.57 & 2.34 & 18.01 & 0.70 & - & - & 1.84 & 1.14 \\
\hline & & & & & & & & & & & & \\
\hline \multirow{6}{*}{ 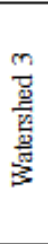 } & & 1 & 35.00 & 79.99 & 2.49 & 2.01 & 2.29 & - & 4.38 & 20.00 & 2.50 & 1.88 \\
\hline & & 2 & 8.00 & 64.91 & 4.05 & 3.06 & 8.11 & 0.81 & 4.00 & 5.00 & 2.50 & 1.50 \\
\hline & & 3 & 2.00 & 26.20 & 3.27 & 1.47 & 13.10 & 0.40 & 2.00 & 2.00 & 2.00 & 0.00 \\
\hline & & 4 & 1.00 & 39.94 & 3.32 & 3.20 & 39.94 & 1.52 & - & - & - & - \\
\hline & Total & - & 46.00 & 211.04 & 13.13 & 9.74 & 63.44 & 2.74 & 2.59 & - & 7.00 & 3.38 \\
\hline & Mean & - & - & - & 2.63 & 1.95 & 12.69 & 0.68 & - & - & 1.75 & 0.84 \\
\hline
\end{tabular}

\section{Drainage Network Analysis}

Stream Order $(\mathrm{Su})$

Stream ordering is the first step to be performed for the quantitative study of the river basin. There are four various type of stream ordering systems that are available (Gravelius, 1914; Horton, 1945; Strahler, 1952; Schideggar, 1970). The stream ordering systems had been first promoted by Horton (1945), but Strahler (1952) has expected ahead to this ordering system with some changes (Rai et al., 2017a \& 2017b; Rai et al., 2018). The information of stream order number is advantageous in connecting to the size of its contributing basin based on a hierarchic ranking of streams (Singh et al., 2013). Stream order of the Varuna basin area 
was calculated based on Strahler (1964). The study area has a 5th order main channel which is the Varuna River and 4th order stream domination in watershed W1, W2 and W3 of the drainage basin (Fig 3) and it was found that the maximum stream frequency was in the case of first order streams (Table 1 and 2).

Plate 1: (a to c) Varuna River and its Surrounding Land Use (d) a Dry Stream in Varun River BasiN

(a)
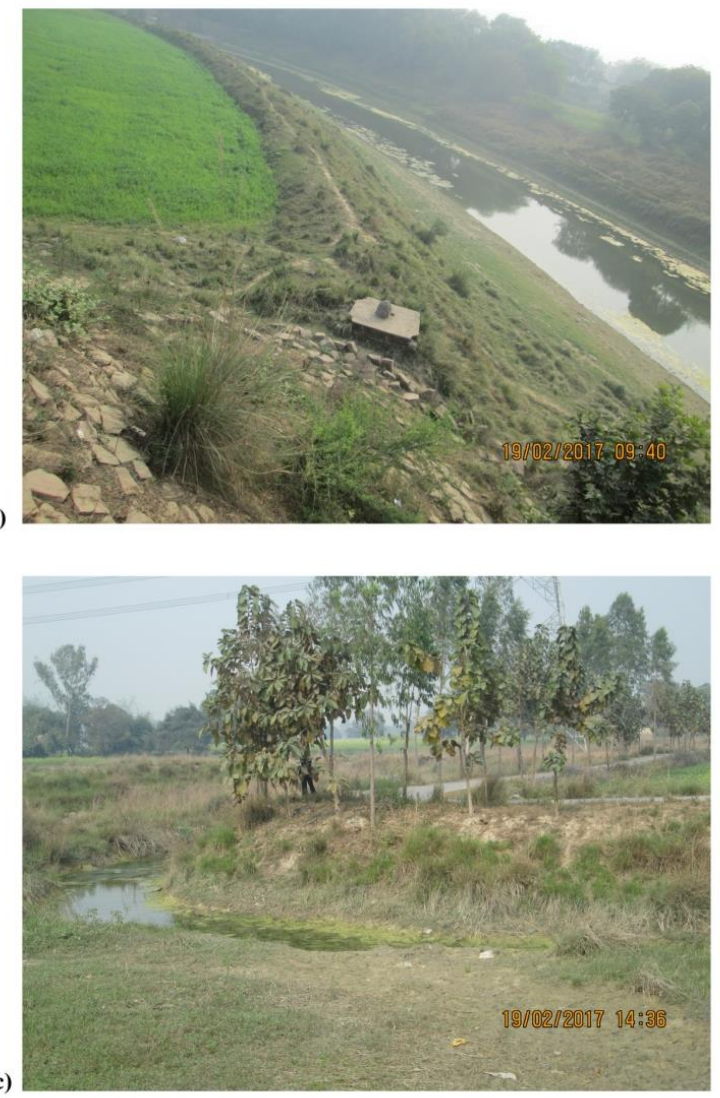

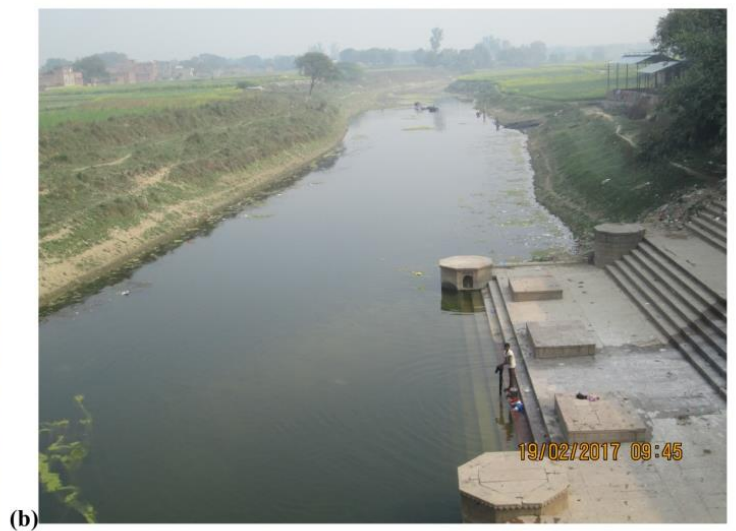

(b)

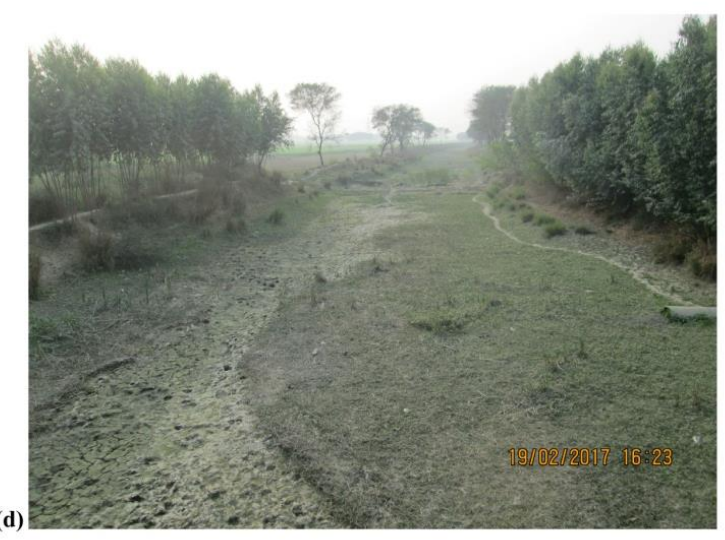


Rai, P.K. \& Singh, P. et al.: Geospatial approach for quantitative drainage morphometric analysis of Varuna river basin, India

Fig. 3: Catchment of Varuna River

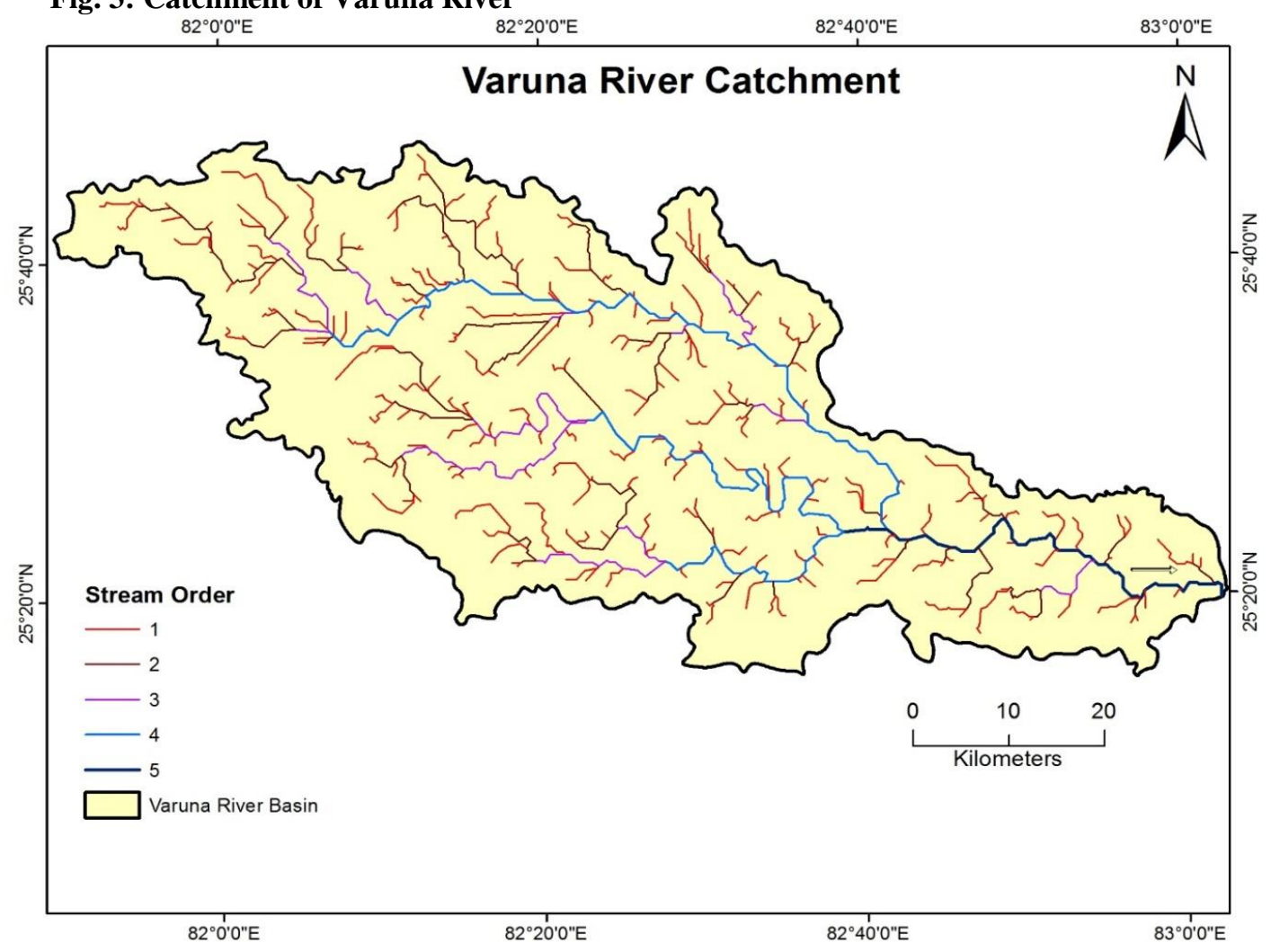

\section{Stream Length $(\mathrm{Lu})$}

The stream length $(\mathrm{Lu})$ has been calculated on the basis of the Horton's law. Stream length is one of the most important hydrological characteristics of the area as it gives information about surface runoff characteristics. The river of quite a small length is a characteristic of regions with steep slopes and better textures. Rivers having considerably longer lengths are commonly suggestive of smoother slope. In general, the total length of river section is highest in first order stream since the length is inversely proportional to the stream order. The numbers of streams of various orders in a watershed of the study basin were counted and their lengths from mouth to drainage divide were measured with the help of ArcGIS software. The total stream lengths of the Varuna basin have various orders, which were computed with the help of ASTER data in ArcGIS-10.3 software. Calculation of stream length favors the theory that geometrical similarity is preserved usually in watershed of increasing stream order (Horton, 1932, 1945; Magesh et al., 2011, 2012, 2013; Strahler, 1964; Pareta et al., 2011; Pareta \& Pareta 2012; Rai et al., 2014). The total stream length in basin was $1282.14 \mathrm{~km}$. (Table 1) and its three watersheds had total stream length of $564.18 \mathrm{~km}, 240.73 \mathrm{~km}$ and $211.04 \mathrm{~km}$ individually (Tables 2 and 3). 
Table 3: Drainage Network of the Study Area

\begin{tabular}{|c|c|c|c|c|c|c|}
\hline $\begin{array}{c}\text { Stream } \\
\text { Property }\end{array}$ & Formula/Method & References & $\begin{array}{c}\text { Main River } \\
\text { channel }\end{array}$ & W 1 & W 2 & W 3 \\
\hline Stream order $(\mathrm{u})$ & Hierarchical rank & Strahler (1964) & 5.00 & \multicolumn{3}{|c|}{4.00} \\
\hline $\begin{array}{l}\text { Stream length } \\
(\mathrm{Lu})\end{array}$ & Length of the stream & Horton (1945) & 1282.14 & 564.18 & 240.73 & 211.04 \\
\hline $\begin{array}{l}\text { Mean Stream } \\
\text { Length (Lsm) }\end{array}$ & $\mathrm{Lsm}=\mathrm{Lu} / \mathrm{Nu}$ & Strahler (1964) & 4.39 & 3.89 & 4.38 & 4.59 \\
\hline $\begin{array}{l}\text { Stream Length } \\
\text { Ratio (RL) }\end{array}$ & $\mathrm{RL}=\mathrm{Lu} / \mathrm{Lu}-1$ & Horton (1945) & 0.62 & 0.79 & 0.70 & 0.68 \\
\hline $\begin{array}{c}\text { Bifurcation Ratio } \\
(\mathrm{Rb})\end{array}$ & $\mathrm{Rb}=\mathrm{Nu} / \mathrm{Nu}+1$ & Schumm (1956) & 3.92 & 4.99 & 2.98 & 2.59 \\
\hline $\begin{array}{c}\text { Mean Bifurcation } \\
\text { Ratio (Rbm) }\end{array}$ & $\begin{array}{c}\text { Rbm = Average of } \\
\text { bifurcation ratios of all } \\
\text { order }\end{array}$ & Strahler (1957) & 0.98 & 1.25 & 0.75 & 0.65 \\
\hline $\begin{array}{l}\text { Rho Coefficient } \\
(\rho)\end{array}$ & $\mathrm{RL} / \mathrm{Rb}$ & Horton (1945) & 0.16 & 0.16 & 0.24 & 0.26 \\
\hline $\begin{array}{c}\text { Direct } \\
\text { Bifurcation Ratio } \\
(\mathrm{Rdb})\end{array}$ & $\mathrm{Rdb}=\mathrm{Ndu} / \mathrm{Nu}+1$ & - & 3.02 & 3.22 & 1.84 & 1.75 \\
\hline $\begin{array}{l}\text { Bifurcation Index } \\
\text { (R) }\end{array}$ & $\mathrm{R}=\mathrm{Ru}-\mathrm{Rdb}$ & - & 0.89 & 0.53 & 1.14 & 0.84 \\
\hline
\end{tabular}

\section{Stream Number $(\mathrm{Nu})$}

The number of stream segments in each order is known as stream number. Horton (1945) states that the number of stream segments of each order create an inverse geometric sequence with order number. (Rai et al., 2017a \& 2017b; Rai et al., 2018; Magesh et al., 2011, 2012 and 2013; Rai et al., 2014) In Varuna basin and its watershed, it was calculated that the number of streams gradually decreases as the stream order increases; the variation in stream order and size of tributary basins largely depends on physiographical, geomorphological and structural characteristics of the basin. The total number of stream segments including the Varuna River was identified to be 292 which have stream order 5, whereas the three watersheds have 145, 55 and 46 stream segments having 4th ordered streams (Fig 4) (Table 2). The higher amount of first order streams indicates the intensity of permeability and infiltration (Chitra et al., 2011). 
Rai, P.K. \& Singh, P. et al.: Geospatial approach for quantitative drainage morphometric analysis of Varuna river basin, India

Fig. 4: Varuna Basin and its Watersheds

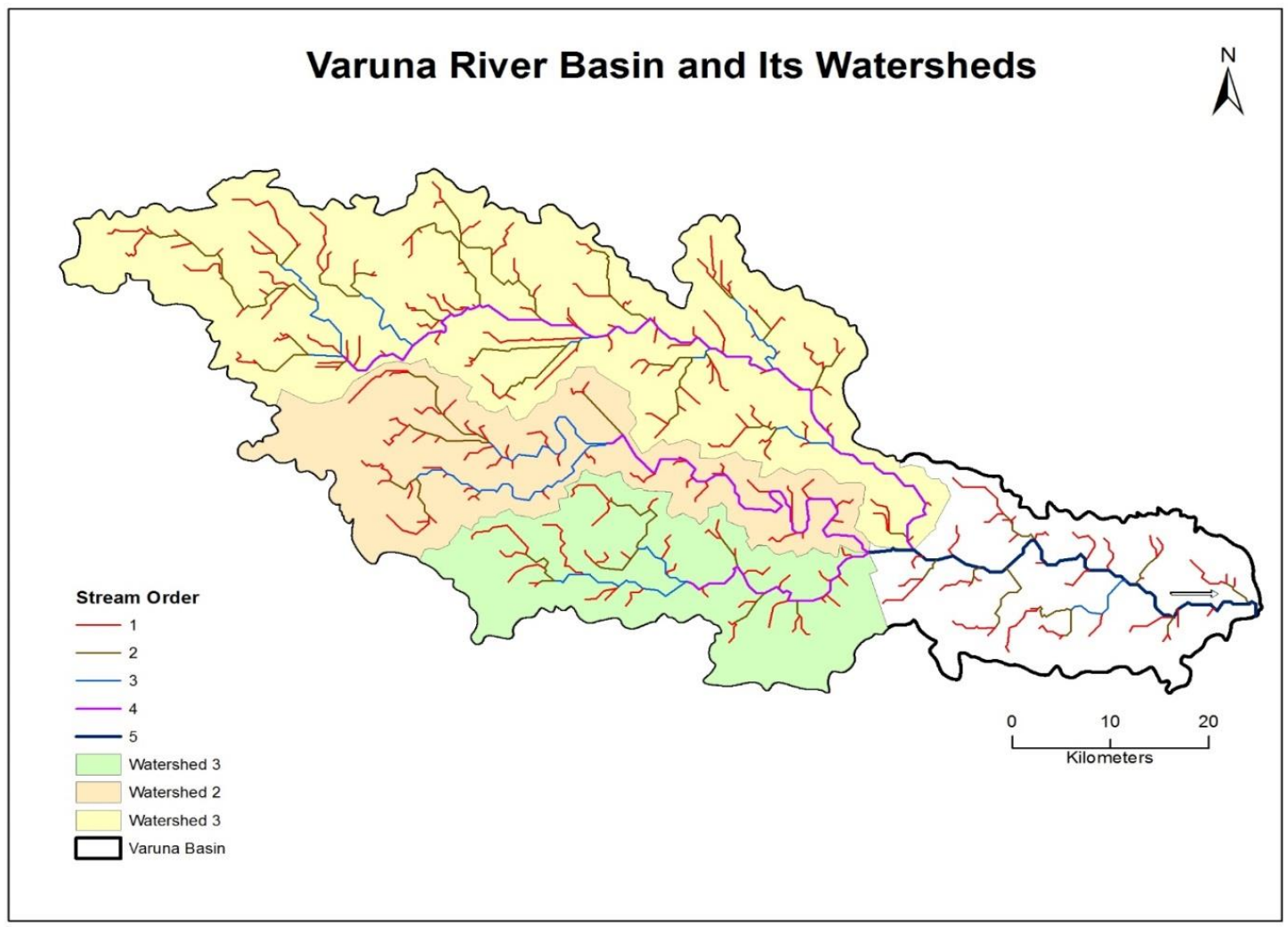

Mean Stream Length (Lsm)

Mean Stream length is a dimension less property revealing the characteristic size of components of a drainage network and its contributing watershed surfaces (Strahler, 1964). It is obtained by dividing the total length of streams of an order by total number of stream segments of that order. Stream Length Ratio (RL) states that it is the ratio of the mean (Lu) of stream segments of an order ( $\mathrm{Su}$ ) to mean length of segments of the next lower order (Lu-1), which tends to be constant throughout the successive orders of a basin (Horton, 1945; Strahler, 1964, Pareta et al., 2011, Magesh et al., 2012, 2013 and Rai et al., 2014). Mean stream length of Varuna basin was calculated based on the method proposed by Strahler (1964) and was obtained to be 2.60 to 51.44 (Table 1). Calculation of Mean stream length (Lsm) and stream length ratio (RL) of the three watersheds of the Varuna basin were based on stream-order and are shown in Table 2.

Bifurcation Ratio $(\mathrm{R} b)$

The ratio of the number of the stream segments of given order ' $\mathrm{Nu}$ ' to the number of streams in the next higher order ( $\mathrm{Nu}+1)$ is term as bifurcation ratio. Horton (1945) considered the bifurcation ratio as index of relief and dissections. Strahler (1957) confirmed that bifurcation ratio displays a small range of variation for different regions or different environments except where the powerful geological control dominates. It was identified that 
the $\mathrm{R} b$ is not same from one order to its next stream order and these anomalies are dependent upon the geological and lithological development of the drainage basin (Strahler, 1964; Chow, 1964; Verstappen, 1983; Rai et al., 2014; Singh et al., 2014). The bifurcation ratio $(\mathrm{R} b)$ is a dimensionless property and it normally ranges from 3.0 to 5.0. The lower values of $\mathrm{R} b$ are characteristics of the watersheds which have suffered less structural disturbances (Strahler, 1964; Verstappen, 1983) and their drainage pattern has not been distorted because of the geological or structural control (Schumm, 1956; Chow, 1964; Nautiyal, 1994; Chopra et al., 2005). The $\mathrm{R} b$ of the Varuna basin as calculated varied from 3 to 4.5 (Tables 1 and 3 ).

\section{Mean Bifurcation Ratio (Rbm)}

To arrive at a more representative bifurcation number Strahler (1953) used a weighted mean bifurcation ratio ( $\mathrm{Rbm}$ ) acquired by multiplying the bifurcation ratio for each successive pair of orders by the total number of streams involved in the ratio and taking the mean of the sum of these values (Rai et al., 2017a \& 2017b, Rai et al., 2018; Magesh et al., 2012, 2013; Rai et al., 2014). Mean Bifurcation Ratio (R bm) of Varuna basin was calculated based on the method proposed by Strahler (1957) and it was found to be 0.98 (Tables 1 and 3). Mean Bifurcation Ratio of Varuna basin is low, which designates that the drainage pattern of the basin has been normal without any the structural disturbances (Verstappen, 1983; Singh et al., 2013; Rai et al., 2014).

Direct Bifurcation Ratio $\left(\mathrm{R}_{\underline{\mathrm{db}}}\right)$

The direct bifurcation ratio is the measure of the degree of branching within the hydrographic network (Horton, 1945; Strahler, 1952) and given as equation (1).

$$
R_{d b}=\frac{N_{d u}}{N_{u}+1}
$$

where $N_{d u}$ represents the number of fluvial segments of a given order, $N_{u}+1$ is the number of segments of next higher order (Guarnieri \& Pirrotta, 2008).

This ratio describes the structure of the hydrographic network without considering hierarchical anomalies. Bifurcation index is given as

$R=R_{b}-R_{d b}$

It can give useful information on the erosive processes and on the degree of evolution of the basin (Guarnieri \& Pirrotta, 2008). The Direct Bifurcation parameters relative to this analysis demonstrated that Varuna and its sub-watershed were calculated to be 3.03, 3.22, 1.84 and 1.75 respectively (Table 1 and 3 ).

\section{Rho Coefficient $(\rho)$}

The Rho coefficient is a significant parameter relating drainage density to physiographic development of a watershed which facilitates evaluation of storage capacity of drainage network and hence, a determinant of ultimate degree of drainage development in a given watershed (Horton, 1945). Rho values of the Varuna basin was 0.16 (Table 3).

\section{Basin Geometry}

\section{Length of Main Channel (CI)}

This is the length along the longest watercourse from the outflow point of designated watershed to the upper limit of the watershed boundary (Pareta et al., 2011). Length of Main channel (CI) of the study area was computed by ArcGIS-10.3 software, which was then found to be $178 \mathrm{kms}$. (Table 4). 
Rai, P.K. \& Singh, P. et al.: Geospatial approach for quantitative drainage morphometric analysis of Varuna river basin, India

Table 4: Basin Geometry of the Study Area

\begin{tabular}{|c|c|c|c|c|c|c|}
\hline $\begin{array}{l}\text { Stream } \\
\text { Property }\end{array}$ & Formula/Method & References & $\begin{array}{c}\text { Main } \\
\text { River } \\
\text { channel }\end{array}$ & W 1 & W 2 & W 3 \\
\hline $\begin{array}{l}\text { Basin Length } \\
(\mathrm{Lb}) \text { in kms. }\end{array}$ & GIS Software & Schumm (1956) & 128.63 & 92.3 & 57 & 44 \\
\hline $\begin{array}{l}\text { Basin Width (W) } \\
\text { in kms. }\end{array}$ & GIS Software & Schumm (1956) & 55 & 23 & 17 & 14 \\
\hline $\begin{array}{c}\text { Mean Basin } \\
\text { Width }(\mathrm{Wb}) \text { in } \\
\text { kms. }\end{array}$ & GIS Software & Schumm (1956) & 32.66 & - & - & - \\
\hline $\begin{array}{l}\text { Basin Perimeter } \\
(\mathrm{P}) \text { in kms. }\end{array}$ & GIS Software & Schumm (1956) & 421.60 & 276.10 & 176.90 & 134.48 \\
\hline $\begin{array}{l}\text { Basin Area (A) in } \\
\text { sq. kms. }\end{array}$ & GIS Software & Schumm (1956) & 3445.14 & 1386.75 & 593.01 & 460.32 \\
\hline $\begin{array}{c}\text { Relative } \\
\text { Parameter(Pr) }\end{array}$ & $\operatorname{Pr}=\mathrm{A} / \mathrm{P}$ & Schumm (1956) & 8.17 & 5.02 & 3.35 & 3.42 \\
\hline $\begin{array}{l}\text { Length Area } \\
\text { Relation (Lar) }\end{array}$ & Lar $=1.4 *(A)^{0.6}$ & Hack (1957) & 185.55 & 107.48 & 64.56 & 55.46 \\
\hline Lemniscate's (k) & $\mathrm{k}=(\mathrm{Lb})^{2} / \mathrm{A}$ & Chorely (1957) & 4.80 & 6.14 & 5.48 & 4.21 \\
\hline $\begin{array}{l}\text { Form Factor } \\
\text { Ratio (Ff) }\end{array}$ & $\mathrm{Ff}=\mathrm{A} /(\mathrm{Lb})^{2}$ & Horton (1932) & 0.21 & 0.16 & 0.18 & 0.24 \\
\hline $\begin{array}{c}\text { Shape Factor } \\
\text { Ratio (Sf) }\end{array}$ & $\mathrm{Sf}=(\mathrm{Lb})^{2} / \mathrm{A}$ & Horton (1932) & 4.80 & 6.14 & 5.48 & 4.21 \\
\hline $\begin{array}{c}\text { Elongation Ratio } \\
(\mathrm{Re})\end{array}$ & $\operatorname{Re}=2 / \mathrm{Lb} *(\mathrm{~A} / \pi)^{0.5}$ & Schumm (1956) & 0.52 & 0.46 & 0.48 & 0.55 \\
\hline $\begin{array}{l}\text { Circularity Ratio } \\
(\mathrm{Rc})\end{array}$ & $\mathrm{Rc}=12.57 *\left(\mathrm{~A} / \mathrm{P}^{2}\right)$ & Miller (1960) & 0.24 & 0.23 & 0.24 & 0.32 \\
\hline $\begin{array}{c}\text { Compactness } \\
\text { Coefficient }(\mathrm{Cc}) \\
\end{array}$ & $\mathrm{Cc}=0.2841 * \mathrm{P} / \mathrm{A}^{0.5}$ & Gravelius (1914) & 2.04 & 2.11 & 2.06 & 1.78 \\
\hline Fitness Ratio (Rf) & $\mathrm{Rf}=\mathrm{Cl} / \mathrm{P}$ & Melton (1957) & 0.42 & 0.42 & 0.54 & 0.47 \\
\hline $\begin{array}{l}\text { Wandering Ratio } \\
\text { (Rw) }\end{array}$ & $\mathrm{Rw}=\mathrm{Cl} / \mathrm{Lb}$ & $\begin{array}{c}\text { Smart \& Surkan } \\
(1967)\end{array}$ & 1.38 & 1.26 & 1.68 & 1.44 \\
\hline $\begin{array}{c}\text { Watershed } \\
\text { Eccentricity }(\mathrm{T})\end{array}$ & $\mathrm{T}=\left(\left(\mathrm{L}^{2}-\mathrm{W}^{2}\right)^{0.5}\right) / \mathrm{W}$ & Black (1972) & 2.11 & 3.89 & 3.20 & 2.98 \\
\hline $\begin{array}{l}\text { Down valley } \\
\text { distance (Vi) }\end{array}$ & GIS Software & Mueller (1968) & $\begin{array}{l}51(5 \text { th } \\
\text { order } \\
\text { stream } \\
\text { length }) \\
\end{array}$ & $\begin{array}{l}90.87(4 \mathrm{t} \\
\mathrm{h} \text { order } \\
\text { stream } \\
\text { length }) \\
\end{array}$ & $\begin{array}{l}57.34(4 \mathrm{t} \\
\mathrm{h} \text { order } \\
\text { stream } \\
\text { length }) \\
\end{array}$ & $\begin{array}{c}39.94(4 \mathrm{t} \\
\mathrm{h} \text { order } \\
\text { stream } \\
\text { length) }\end{array}$ \\
\hline
\end{tabular}




\begin{tabular}{|c|c|c|c|c|c|c|}
\hline $\begin{array}{l}\text { Main Channel } \\
\text { Length }(\mathrm{Cl}) \text { in } \\
\text { kms. }\end{array}$ & GIS Software & - & 178.00 & 116.19 & 95.51 & 63.34 \\
\hline $\begin{array}{l}\text { Valley Length } \\
(\mathrm{Vl}) \text { in kms. }\end{array}$ & GIS Software & - & 124.00 & 95.45 & 56.56 & 42.30 \\
\hline $\begin{array}{c}\text { Minimum Aerial } \\
\text { Distance (Adm) } \\
\text { in kms. }\end{array}$ & GIS Software & - & 33.00 & 10.66 & 4.34 & 10.54 \\
\hline $\begin{array}{l}\text { Channel Index } \\
(\mathrm{Ci})\end{array}$ & $\begin{array}{c}\mathrm{Ci}=\mathrm{Cl} / \operatorname{Adm}(\mathrm{H} \& \\
\mathrm{TS})\end{array}$ & Mueller (1968) & 5.39 & 10.90 & 22.01 & 6.01 \\
\hline Valley Index (Vi) & $\mathrm{Vi}=\mathrm{Vl} / \operatorname{Adm}(\mathrm{TS})$ & Mueller (1968) & 3.76 & 8.95 & 13.03 & 4.01 \\
\hline $\begin{array}{c}\text { Standard } \\
\text { Sinuosity Index } \\
(\mathrm{Ssi})\end{array}$ & $\mathrm{Ssi}=\mathrm{Ci} / \mathrm{Vi}$ & Mueller (1968) & $\begin{array}{c}1.44 \\
<1.5 \\
\text { sinous } \\
\text { shape }\end{array}$ & $\begin{array}{c}1.22< \\
1.5 \\
\text { sinous } \\
\text { shape }\end{array}$ & $\begin{array}{c}1.69 \\
>1.5 \\
\text { Minderi } \\
\text { ng shape }\end{array}$ & 1.50 \\
\hline $\begin{array}{c}\text { Hydraulic } \\
\text { Sinuosity Index } \\
(\mathrm{Hsi}) \% \\
\end{array}$ & $\begin{array}{c}\mathrm{Hsi}=((\mathrm{Ci}-\mathrm{Vi}) /(\mathrm{Ci}- \\
1)) * 100\end{array}$ & Horton (1945) & 37.24 & 19.65 & 42.72 & 39.85 \\
\hline $\begin{array}{c}\text { Topographic } \\
\text { Sinuosity Index } \\
\text { (Tsi) } \%\end{array}$ & $\begin{array}{c}\mathrm{Tsi}=((\mathrm{Vi}-1) /(\mathrm{Ci}- \\
1)) * 100\end{array}$ & Schumm (1965) & 62.76 & 80.35 & 57.28 & 60.15 \\
\hline $\begin{array}{l}\text { Length of } \\
\text { Overland Flow } \\
\text { (Lg) in kms. }\end{array}$ & $\mathrm{Lg}=(\mathrm{A} / 2) * \mathrm{Lu}$ & Horton (1945) & 5.37 & 4.92 & 4.93 & 4.36 \\
\hline $\begin{array}{c}\text { Texture Ratio } \\
(\mathrm{Rt})\end{array}$ & $\mathrm{Rt}=\mathrm{N} 1 / \mathrm{P}$ & Schumm (1965) & 0.54 & 0.40 & 0.25 & 0.26 \\
\hline
\end{tabular}

Channel Index (Ci) \& Valley Index (Vi)

The river channel has been divided into number of segments as suggested by Muller (1968) for determination of sinuosity parameter. The measurement of channel's length, length of valley, and shortest distance from the source to the mouth of the river (Adm) i.e. air lengths are used to compute the value of Channel index, and valley index and results are shown in Table 4. (Pareta, 2010)

\section{Length of the Basin (Lb)}

Schumm (1956) defined the basin length as the longest dimension of the basin parallel to the main drainage line. Gregory (1977) defined the basin length as the longest length of the basin in which one end being the mouth. Gardiner (1975) defined the basin length as the length of the line of a basin from the mouth to a point on the perimeter equidistant from the basin mouth in either direction. Length of the Varuna basin was calculated to be approximately $128.63 \mathrm{Kms}$ and length of its three watersheds resulted $92.3 \mathrm{~km}, 57 \mathrm{~km}$ and 44 $\mathrm{km}$. (Table 4). 
Rai, P.K. \& Singh, P. et al.: Geospatial approach for quantitative drainage morphometric analysis of Varuna river basin, India

\section{Basin Area (A)}

The area of the watershed is another important parameter like the length of the drainage stream. Schumm (1956) established an interesting relation between the total watershed area and the total stream length, which are supported by the contributing areas. Areal extension of the Varuna basin was 3445.14 sq. kms. (Table 4). Out of three watersheds of the Varuna basin, the watershed W1 had largest drainage area (1386.75 sq. kms.) and W2 had a moderated drainage area (593.01 sq. kms.), whereas watershed W3 covered a small drainage area (460.32 sq. kms.).

\section{Basin Perimeter $(\mathrm{P})$}

Basin perimeter is the outer boundary of the watershed that enclosed its area. It is measured along the divides between the adjacent watersheds and may be used as an indicator of watershed size and shape. Basin perimeter of the study area was calculated in GIS platform, which resulted to be $421.60 \mathrm{~km}$. (Table 4).

\section{Length Area Relation (Lar)}

Hack (1957) identified that for a large number of basins, the stream length and basin area is associated by a simple power function as follows: Lar $=1.4 * \mathrm{~A}^{0.6}$ (Pareta et al., 2011; Pareta \& Pareta, 2012). Lar value of the Varuna basin was calculated using the same and was found to be approximately 185.55 (Table 4).

\section{Lemniscate's (k)}

Chorely (1957), express the Lemniscate's value to compute the slope of the basin. The Lemniscates $(\mathrm{k})$ value for the Varuna basin was 4.80 (Table 4), which displays that the watershed captures a maximum area beginning with a large number of higher stream order (Rai et al., 2017a \& 2017b; Rai et al., 2018).

\section{Form Factor (Ff)}

Form factor may be demarcated as the ratio of basin area to square of the basin length (Horton, 1932). The form factor value would vary between 0 and 1 and may always be less than 0.754 (for a perfectly circular watershed). Higher value indicates circular shape while lower value shows elongated shape of the basin. Form Factor (Ff) of Varuna basin is 0.21 that's gives a little elongated shape (Table 4).

\section{Elongation Ratio (Re)}

According to Schumm (1965), 'elongation ratio' is defined as the ratio of diameter of a circle of the same area of the basin to the maximum basin length. Strahler (1952) states that elongation ratio runs between 0.6 and 1.0 over a wide variety of climatic and geological types. The varying slopes of watershed can be classified with the help of the index of elongation ratio, i.e. circular (0.9-0.10), oval (0.8-0.9), less elongated (0.7-0.8), elongated $(0.5-0.7)$, and more elongated $(<0.5)$ for tectonically high active, active, slightly active and inactive settings, respectively (Sharma et al., 2015). The computed elongation ratio of Varuna basin was 0.52 , which represents the basin is elongated. (Table 4) Typical values are close to 1.0 for regions of very low relief and are between 0.6 and 0.8 for regions of strong relief and steep ground slope. During the study, for individual watersheds, the lowest value of Re was observed in $\mathrm{W} 1$ and $\mathrm{W} 2$, which was 0.46 and 0.48 respectively, while highest value was observed as 0.55 in W3 watershed. (Table 4) The elongation ratio has an important hydrological consequence because, opposite to more circular catchments, precipitation 
delivered during a storm in highly elongated catchment has to cover larger distance to reach the catchment outlet.

\section{Texture Ratio (Rt)}

According to Schumm (1965), texture ratio is an important factor in the drainage morphometric analysis which depends on the underlying lithology, infiltration capacity and relief aspect of the terrain. The texture ratio is expressed as the ratio between the first order stream and perimeter of the basin i.e. $R t=\frac{N 1}{P}$ and it is mainly dependent on the underlying lithology, infiltration capacity and relief aspects of the topography. (Rai et al., 2017a \& 2017b; Rai et al., 2018) In the present study, the texture ratio of the Varuna basin was 0.54 and hence is categorized as confined in nature (Table 4) and watersheds have similar characteristic and nature that is $0.40,0.25$ and 0.26 , which indicates their tendency to be more confined in nature.

\section{Circularity Ratio (Rc)}

For the out-line form of watershed Strahler (1964) and Miller (1953) used a dimensionless circularity ratio as a quantitative method. Circularity ratio is defined as the ratio of watershed area to the area of a circle having the same perimeter as the watershed and it is pretentious by the lithological character of the watershed. Miller (1953) has described the basin of the circularity ratios range from 0.40 to 0.50 , which indicates strongly elongated and highly permeable homogenous geologic materials (Pareta et al., 2011; Pareta \& Pareta, 2012; Rai et al., 2014; Singh et al., 2014). The circularity ratio value 0.24 of the Varuna basin corroborates the Miller's (1960) range, which indicates that the watershed is less elongated in shape, moderate discharge of runoff and permeability of the subsoil condition (Table 4). The range of $\mathrm{Rc}$ value of three watersheds are $0.23,0.24$ and 0.32 respectively (Table 4 ).

\section{Compactness Coefficient (Cc)}

According to Gravelius (1914), compactness coefficient of a watershed is the ratio of perimeter of watershed to circumference of circular area, which equals the area of the watershed. The $\mathrm{Cc}$ is independent of size of watershed and dependent only on the slope (Rai et al., 2017a \& 2017b; Rai et al., 2018). The compactness coefficient of Varuna basin is 2.04 (Table 4) and its watersheds have 2.11,2.06 and 1.78 in order which shows the basin has less convincing nature.

\section{Fitness Ratio (Rf)}

Melton (1957) stated that, the ratio of main channel length to the length of the watershed perimeter is fitness ratio, which is a measure of topographic fitness (Rai et al., 2017a \& 2017b; Rai et al., 2018). The fitness ratio for Varuna basin is 0.42 (Table 4).

\section{Wandering Ratio (Rw)}

According to Smart \& Surkan (1967), wandering ratio is defined as the ratio of the main stream length to the valley length. Valley length is the straight-line distance between outlet of the basin and the farthest point on the ridge (Pareta et al., 2011; Pareta \& Pareta, 2012). The wandering ratio of the Varuna basin is 1.38 with watersheds $1.26,1.68$ and 1.44 (Table 4) which indicates river outright and basin has plain nature. 
Rai, P.K. \& Singh, P. et al.: Geospatial approach for quantitative drainage morphometric analysis of Varuna river basin, India

Watershed Eccentricity $(\mathrm{t})$

Black (1972) has given the expression for watershed eccentricity, which is given as equation (3):

$t=\frac{\left[\left(\mathrm{Lcm}^{2}-W \mathrm{Cm}^{2}\right)\right]^{0.5}}{W c m}$

Where, $\mathrm{t}=$ Watershed eccentricity, a dimensionless factor, $\mathrm{L} \mathrm{cm}=$ Straight length from the watershed mouth to the centre of mass of the watershed, and $\mathrm{W} \mathrm{cm}=$ Width of the watershed at the centre of mass and perpendicular to L cm (Rai et al., 2017a \& 2017b; Rai et al., 2018). Watershed eccentricity shows the shape of the watershed to an ellipse for which the major axis is twice the minor axis. Watershed eccentricity of the Varuna river basin is 2.11 (Table 4).

\section{Standard Sinuosity Index (Ssi)}

Sinuosity deals with the pattern of channel of a drainage basin. Sinuosity has been defined as the ratio of channel length to down valley distance (Pareta et al., 2011; Pareta \& Pareta, 2012). In general, its value varies from 1 to 4 or more. River's nature like straight having SI < 1.05, small meandering SI = 1.05-1.3, moderate meandering SI = 1.3-1.5 and meandering SI $>1.5$ (Wolman \& Miller, 1964; Mueller, 1968). Sinuosity index of Varuna basin was calculated by using Muller's (1968) theory and was found to be 1.44 and for watershed W1 was 1.22 , which indicates that river has moderate meandering nature while $\mathrm{W} 2$ and $\mathrm{W} 3$ have 1.69 and 1.50 respectively, which shows it is meandering in nature (Table 4).

\section{Topographic (TSi) and Hydraulic Sinuosity Index (HSi)}

The hydraulic sinuosity index and topographic sinuosity index are significant parameter in defining the stage of river basin development as well as the controlling aspects of sinuosity. HSi and TSi value of the Varuna River is $37.24 \%$ and $62.76 \%$ respectively (Table 4). From the sinuosity analysis, it can be noticed that the influence of topography on sinuosity decreases as the river channel shift from upper to lower reaches of the basin. Subsequently, role of hydraulic factors become protuberant in the lower reaches. It is clear that as altitude decreases, TSi decreases and accordingly HSi increases.

\section{Drainage Texture Analysis}

\section{Drainage Texture (Dt)}

The treatment of drainage density does not appear to be complete except when the qualitative nomenclatures fit to the quantitative limits. Drainage density, no doubt, is a well-defined expression of texture than the measures of spacing as it includes all the channels in the grid or a basin (Singh, 1980). Drainage texture (Dt) is a vital concept of geomorphology which refers towards the relative spacing of drainage lines. Drainage texture depends on the underlying lithology, infiltration capacity and relief aspect of the terrain. Dt is total number of stream segments of all orders per watershed perimeter of that area (Horton, 1945). Drainage texture has been classified into five different textures i.e., very coarse $(<2)$, coarse (2 to 4), moderate (4 to 6), fine (6 to 8) and very fine (> 8) (Smith, 1950; Rai et al., 2017a \& 2017b; Rai et al., 2018). In the present study, the drainage texture of the basin was found to be 0.69 (Table 5). It specifies that group has very coarse drainage texture. Drainage texture (Dt) of individual watersheds of the Varuna basin as calculated was $0.53,0.31$ and 0.34 respectively (Table 5 ). 
Table 5: Drainage Texture Analysis of the Study Area

\begin{tabular}{|c|c|c|c|c|c|c|}
\hline Stream Property & Formula/Method & References & $\begin{array}{c}\text { Main River } \\
\text { channel }\end{array}$ & W 1 & W 2 & W 3 \\
\hline $\begin{array}{l}\text { Drainage Density (Dd) in } \\
\mathrm{km} / \mathrm{kms}^{2}\end{array}$ & $\mathrm{Dd}=\mathrm{Lu} / \mathrm{A}$ & Horton (1932) & 0.37 & \multicolumn{2}{|c|}{0.41} & 0.46 \\
\hline Drainage Texture (Dt) & $\mathrm{Dt}=\mathrm{Nu} / \mathrm{P}$ & Horton (1945) & 0.69 & 0.53 & 0.31 & 0.34 \\
\hline Stream Frequency $(\mathrm{Fs})$ & $\mathrm{Fs}=\mathrm{Nu} / \mathrm{A}$ & Horton (1932) & 0.08 & 0.10 & 0.09 & 0.10 \\
\hline $\begin{array}{l}\text { Length Overland flow } \\
(\mathrm{Lg}) \text { in kms. }\end{array}$ & $\mathrm{Lg}=1 / \mathrm{D} * 2$ & Faniran (1968) & 5.37 & 4.92 & 4.93 & 4.36 \\
\hline Infiltration Number (If) & If $=\mathrm{Fs} * \mathrm{Dd}$ & Faniran (1968) & 0.03 & 0.04 & 0.04 & 0.05 \\
\hline $\begin{array}{c}\text { Constant of Channel } \\
\text { Maintenance }\left(\mathrm{kms}^{2} / \mathrm{km}\right) \\
\end{array}$ & $\mathrm{C}=1 / \mathrm{Dd}$ & Schumm (1956) & 2.69 & 2.46 & 2.46 & 2.18 \\
\hline Drainage Intensity (Di) & $\mathrm{Di}=\mathrm{Fs} / \mathrm{Dd}$ & Faniran (1968) & 0.23 & 0.26 & 0.23 & 0.22 \\
\hline
\end{tabular}

Table 6: Relief Aspects of the Study Area

\begin{tabular}{|c|c|c|c|c|c|c|}
\hline $\begin{array}{c}\text { Stream } \\
\text { Property }\end{array}$ & Formula/Method & References & $\begin{array}{c}\text { Main River } \\
\text { channel }\end{array}$ & W 1 & W 2 & W 3 \\
\hline $\begin{array}{l}\text { Maximum } \\
\text { Height of the } \\
\text { Basin }(\mathrm{Z}) \text { in } \\
\text { metre }(\mathrm{m})\end{array}$ & GIS Software & - & \multicolumn{4}{|c|}{107} \\
\hline $\begin{array}{l}\text { Height of Basin } \\
\text { Mouth (z) in } \\
\text { metre (m) }\end{array}$ & GIS Software & - & \multicolumn{4}{|c|}{69} \\
\hline $\begin{array}{l}\text { Total Basin } \\
\text { Relief }(\mathrm{H}) \text { in } \\
\text { metre }(\mathrm{m})\end{array}$ & $\mathrm{H}=\mathrm{Z}-\mathrm{Z}$ & Strahler (1952) & \multicolumn{4}{|c|}{38} \\
\hline $\begin{array}{l}\text { Relief Ratio } \\
\quad(\mathrm{Rhl})\end{array}$ & $\mathrm{Rhl}=\mathrm{H} / \mathrm{Lb}$ & Schumm (1956) & 0.30 & 0.41 & 0.67 & 0.86 \\
\hline $\begin{array}{l}\text { Maximum } \\
\text { Relief (Z1) }\end{array}$ & GIS Software & - & \multicolumn{4}{|c|}{107.00} \\
\hline $\begin{array}{c}\text { Absolute Relief } \\
\text { (Ra) }\end{array}$ & GIS Software & - & \multicolumn{4}{|c|}{107.00} \\
\hline
\end{tabular}


Rai, P.K. \& Singh, P. et al.: Geospatial approach for quantitative drainage morphometric analysis of Varuna river basin, India

\begin{tabular}{|c|c|c|c|c|c|c|}
\hline $\begin{array}{c}\text { Relative Relief } \\
\text { Ratio (Rhp) }\end{array}$ & $\mathrm{Rhp}=\mathrm{H}^{*} 100 / \mathrm{P}$ & Melton (1957) & 9.01 & 13.76 & 21.48 & 28.26 \\
\hline $\begin{array}{c}\text { Dissection } \\
\text { Index (Dis) }\end{array}$ & Dis $=\mathrm{H} / \mathrm{Ra}$ & $\begin{array}{c}\text { Singh \& Dubey } \\
\text { (1994) }\end{array}$ & 0.36 & 0.36 & 0.36 & 0.36 \\
\hline $\begin{array}{c}\text { Gradient Ratio } \\
(\mathrm{Rg})\end{array}$ & $\mathrm{Rg}=\mathrm{Z}-\mathrm{z} / \mathrm{Lb}$ & $\begin{array}{c}\text { Sreedevi et al, } \\
(2005)\end{array}$ & 0.30 & 0.41 & 0.67 & 0.86 \\
\hline $\begin{array}{l}\text { Watershed } \\
\text { Slope (Sw) }\end{array}$ & $\mathrm{Sw}=\mathrm{H} / \mathrm{Lb}$ & $\begin{array}{c}\text { Sreedevi et al, } \\
(2005)\end{array}$ & 0.30 & 0.41 & 0.67 & 0.86 \\
\hline $\begin{array}{c}\text { Ruggedness } \\
\text { Number (Rn) }\end{array}$ & $\mathrm{Rn}=\mathrm{Dd} *(\mathrm{H} / 1000)$ & $\begin{array}{c}\text { Patton \& Baker } \\
\quad(1976)\end{array}$ & 0.01 & 0.02 & 0.02 & 0.02 \\
\hline $\begin{array}{c}\text { Melton } \\
\text { Ruggedness } \\
\text { Number (MRn) } \\
\end{array}$ & $\mathrm{MRn}=\mathrm{H} / \mathrm{A}^{0.5}$ & Melton (1957) & 0.65 & 1.02 & 1.56 & 1.77 \\
\hline $\begin{array}{c}\text { Channel } \\
\text { Gradient }(\mathrm{Cg}) \text { in } \\
\mathrm{m} / \mathrm{kms} \text {. }\end{array}$ & $\mathrm{Cg}=\mathrm{H} /\{(\pi / 2) * \mathrm{Clp}\}$ & Broscoe (1959) & 0.14 & 0.21 & 0.25 & 0.38 \\
\hline
\end{tabular}

\section{Stream Frequency (Fs)}

The drainage stream frequency introduced by Horton (1932) means stream frequency (or channel frequency) Fs as the number of stream segments per unit area (Rai et al., 2017a \& 2017b; Rai et al., 2018). The channel segment numbers for unit areas are difficult to be enumerated (Singh, 1980). In the present study, the stream frequency of the Varuna basin was found 0.08 (Table 5). Among the watersheds of the Varuna basin, lower stream frequency had been identified as W1 (0.10), W2 (0.09) and W3 (0.10). Stream or channel frequency density helps as a tool in finding the erosional process operating over an area, to be more precise, the same in relation to the stream orders and their characteristics, provides data which can throw light even on the sequences of relief developments and the degree of ruggedness in the Varuna basin area. Higher frequencies are the measure to show the early stages of the fluvial cycle or rejuvenated erosional activities along the steep slopes (Singh, 1980).

\section{Drainage Density (Dd)}

Drainage density is the stream length per unit area of basin or watershed (Horton, 1932, 1945; Melton, 1958; Strahler, 1952 and 1957) and is another element of drainage analysis. Drainage density is a better quantitative expression to the dissection and analysis of landform, although a function of climate, lithology and structures and relief history of the region can be used as an indirect indicator to explain, those variables as well as the morphogenesis of landform (Rai et al., 2017a \& 2017b; Rai et al., 2018). Drainage density of the Varuna basin as calculated was found to be $0.37 \mathrm{Km} / \mathrm{Km} 2$ and it is signifying moderate drainage densities (Table 5). Watersheds W1 \& W2 have 0.41 and W3 has 0.46 drainage 
densities respectively. High drainage density is the result of weak impervious subsurface material, scant vegetation and mountainous relief (Singh et al., 2013).

\section{Constant of Channel Maintenance (1/D)}

Schumm (1956) used the inverse of drainage density or the constant of channel maintenance as a property of landforms. The constant indicates the number of $\mathrm{Km} 2 / \mathrm{Km}$ of basin surface required to develop and sustain a channel $1 \mathrm{~km}$ long (Pareta et al., 2011; Pareta $\&$ Pareta, 2012). The constant of channel maintenance indicates the relative size of landform units in a drainage basin and has a specific genetic connotation (Strahler, 1957). Channel maintenance constant of the basin was calculated as $2.69 \mathrm{kms} 2 / \mathrm{km}$ (Table 5).

\section{Drainage Intensity (Di)}

Faniran (1968) defines the drainage intensity, as the ratio of the stream frequency to the drainage density. This study shows a low drainage intensity of 0.23 for the Varuna basin (Table 5). This low value of drainage intensity implies that drainage density and stream frequency have a little effect (if any) on the extent to which the surface has been lowered by agents of denudation. With these low values of drainage density, stream frequency and drainage intensity, surface runoff is not easily removed from the watershed or sub-watershed, making it very susceptible to flooding, gully erosion and landslide incidence (Rai et al., 2017a \& 2017b; Rai et al., 2018).

\section{Infiltration Number (If)}

The infiltration number of a watershed is defined as the product of drainage density and stream frequency and given an idea about the infiltration characteristics of the watershed (Rai et al., 2017a \& 2017b; Rai et al., 2018). The infiltration number of Varuna basin was found to be 0.03 (Table 4). Infiltration number (If) of individual watersheds of the Varuna basin W1 and $\mathrm{W} 2$ were 0.04 and $\mathrm{W} 3$ is 0.05 and are given in the Table 5.

\section{Drainage Pattern $(\mathrm{Dp})$}

In the basin, the drainage pattern reflects the influence of slope, lithology and structure. Finally, the study of drainage pattern helps in identifying the stages in the cycle of erosion. Drainage pattern presents some characteristics of drainage basins through drainage pattern and drainage texture. It is possible to deduce the geology of the basin, the strike and dip of depositional rocks, existence of faults and other information about geological structure from drainage patterns. Drainage texture reflects climate, permeability of rocks, vegetation, and relief ratio, etc. Howard (1967) associated drainage patterns to geological information (Pareta et al., 2011; Pareta \& Pareta 2012). Varuna drainage pattern has been recognized to have dendritic drainage pattern (Table 5).

\section{Length of Overland Flow (Lg)}

Horton (1945) used this term to refer to the length of the run of the rain water on the ground surface before it is localized into definite channels. Since this length of overland flow, at an average, is about half the distance between the stream channels, Horton, for the sake of convenience, had taken it to be roughly equal to half the reciprocal of the drainage density (Rai et al., 2017a \& 2017b; Rai et al., 2018). River basins with lower overland flow values also designate that in such basins less rainfall is adequate to pay a substantial volume of surface run off to stream discharge (Muthukrishnan et al., 2013). The investigation of length of overland flow data disclosed that, the Varuna basin (5.37) has an account of their high 
Rai, P.K. \& Singh, P. et al.: Geospatial approach for quantitative drainage morphometric analysis of Varuna river basin, India

value clues, lower stage (old age) and structural build due to the high value of $\mathrm{Lg}(0.61)$ (Table 5).

\section{Relief Characteristics}

\section{Relief Ratio (Rhl)}

Difference in the elevation between the highest point of a watershed and the lowest point on the valley floor is known as the total relief of the river basin. The relief ratio may be defined as the ratio between the total relief of a basin and the longest dimension of the basin parallel to the main drainage line (Schumm, 1956). The possibility of a close correlation between relief ratio and hydrologic characteristics of a basin was suggested by Schumm (1956) who found that sediments loose per unit area is meticulously associated with relief ratios (Rai et al., 2017a \& 2017b; Rai et al., 2018). In the study area i.e. Varuna basin, the value of relief ratio was calculated 0.30 and for watersheds $\mathrm{W} 1$, W2 and W3 it was $0.14,0.67$ and 0.86 respectively (Table 6). It has been perceived that areas with low to moderate relief and slope are measured by moderate value of relief ratios. Low value of relief ratios is mostly due to the resistant basement rocks of the drainage basin and low degree of gradient (Rai et al., 2017a \& 2017b; Rai et al., 2018).

\section{Relative Relief (Rhp)}

The maximum basin relief was attained from the highest point on the watershed perimeter to the mouth of the stream. Using the basin relief $174 \mathrm{~m}$, a relief ratio was computed as suggested by Schumm (1956). Melton's (1957) relative relief was also calculated using the formula given as:

$R_{h p}=\frac{(H * 100)}{P}$

Where, $\mathrm{P}$ is perimeter in meters (Pareta et al., 2011; Pareta \& Pareta, 2012). Relative relief of the Varuna basin was 9.01 and watersheds W1, W2 and W3 had 13.76, 21.48 and 28.26 respectively (Table 6).

\section{Absolute Relief $(\mathrm{Ra})$}

The absolute relief is the difference in elevation between a given location and sea level (Pareta et al., 2011; Pareta \& Pareta, 2012). Absolute relief of the Varuna basin and its watersheds is 107 (Table 6).

\section{Channel Gradient $(\mathrm{Cg})$}

The total drops in elevation from the source to the mouth were found out for the Varuna basin and horizontal distances were calculated along their channels. Channel Gradient $(\mathrm{Cg})$ of the Varuna basin was calculated to be 0.14 (Table 6).

\section{Ruggedness Number $(\mathrm{Rn})$}

Strahler's (1968) ruggedness number is the product of the basin relief and the drainage density and practically combines slope steepness with its length (Rai et al., 2017a \& 2017b; Rai et al., 2018). Calculation of ruggedness number of the Varuna basin resulted to a very low which approximated to 0.01 and watersheds $\mathrm{W} 1, \mathrm{~W} 2$ and $\mathrm{W} 3$ all have 0.02 (Table 6). 
Melton Ruggedness Number (MRn)

The MRn is a slope index that provides specialized representation of relief ruggedness within the watershed (Melton, 1965; Rai et al., 2017a \& 2017b; Rai et al., 2018). MRn of Varuna basin was calculated to be 0.65 and watersheds W1, W2 and W3 have 1.02, 1.56 and 1.77 respectively (Table 6).

\section{Dissection Index (Dis)}

Dissection index is a parameter implying the degree of dissection or vertical erosion and expounds the stages of terrain or landscape development in any given physiographic region or watershed (Singh \& Dubey, 1994). On an average, the values of Dis vary between ' 0 ' (complete absence of vertical dissection/erosion and hence dominance of flat surface) and ' 1 ' (in exceptional cases, vertical cliffs, it may be at vertical escarpment of hill slope or at seashore) (Rai et al., 2017a \& 2017b; Rai et al., 2018). Dis value of Varuna basin and watersheds were 0.36 (Table 6).

\section{Gradient Ratio ( $\mathrm{Rg})$}

Gradient ratio is a vital indicator of channel slope, which allows evaluation of the runoff volume (Sreedevi, 2001 and 2005; Rai et al., 2017a \& 2017b; Rai et al., 2018). Rg value of the Varuna basin was found 0.30 and watersheds $\mathrm{W} 1, \mathrm{~W} 2$ and $\mathrm{W} 3$ have $0.41,0.67$ and 0.86 respectively (Table 6).

\section{CONCLUSION}

Remote sensing and GIS techniques are appropriate tools for morphometric study. Drainage, one of the most significant elements of landforms study, has been analysed in the study. Its distributional patterns, density, frequency and the basin parameters have been estimated and analysed quantitatively. The study discloses different types of morphometric analysis and their influence on soil and topography. The morphometric studies and includes within it the assessment of the drainage basins with respect to density, frequency, bifurcation ratio, stream orders, basin shape, circulatory, sinuosity, elongation and relief ratios etc. Morphometric study of the Varuna River basin represents dendritic drainage pattern and its three watersheds have sub-dendritic drainage pattern with $5^{\text {th }}$ and $4^{\text {th }}$ order drainage respectively. The larger number of first order streams points to uniform lithology and noble slope gradient. Varuna River basin shows very classic drainage texture. The bifurcation ratio of the Varuna River basin is 3.92 which indicate that the basin is normal and the control of drainage network is mainly pronounced by geomorphology. Lower value of bifurcation ratio indicates that the drainage basin is underlined by uniform materials and the streams are usually branched systematically. Drainage density, stated as the length of drainage channels per unit area of the basin helps in better interpretation of the hydrological data of Varuna River. Varuna River basin possess moderated drainage density which is indicative of permeable material, vegetative cover and moderate to low relief. Circularity and elongation ratio shows that the basin has little elongated shaped. The morphometric parameters derived with the help ASTER or SRTM based DEM data through GIS techniques provides a very significant inputs for watershed prioritization and planning. Through watershed prioritization, decision for basin development can be taken by the decision makes and government authorities. 
Rai, P.K. \& Singh, P. et al.: Geospatial approach for quantitative drainage morphometric analysis of Varuna river basin, India

\section{REFERENCES}

Agarwal, C. S. (1998). Study of drainage pattern through aerial data in Naugarh area of Varanasi district U.P. , Journal of the Indian Society of Remote Sensing, 26, pp 169-175.

Angillieri, Y. E. (2008). Morphometric analysis of Colangüil river basin and flash flood hazard, San Juan, Argentina. Environ. Geol., v.55 (1), pp.107-111, DOI: 10.1007/s00254-007-0969-2.

Bates, R. L. \& Jackson, J. A. (1980). Glossary of Geology. 2nd edn. American Geological Institute, $751 \mathrm{pp}$.

Black, P. E. (1972). Hydrograph response to geometric model watershed characteristics and precipitation variables. Journal of Hydrology, 17, 309-329.

Broscoe, A. J. (1959). Quantitative Analysis of Longitudinal Stream Profiles of Small watersheds , Project N. 389-042, Tech. Bep. 18, Geology Department, Columbian University, ONR, Geography Branch, New York.

Chitra, C., Alaguraja, P., Ganeshkumari, K., Yuvaraj, D., Manivel, M. (2011). Watershed characteristics of Kundah sub basin using remote sensing and GIS techniques. Int J Geomatics Geosci 2: 311-335.

Chopra, R., Raman, D. D. and Sharma, P. K. (2005). Morphometric analysis of sub-watersheds in Gurudaspur district, Punjab using remote sensing and GIS techniques. $J$ Indian Soc of Remote sensing 33(4):531-539.

Chow Ven T (1964). Handbook of applied hydrology. McGraw Hill Inc, New York.

Dury, G. H. (1952). Methods of cartographical analysis in geomorphological research, Silver Jubilee Volume, Indian Geographical Society, Madras, 136-139.

Eze, E. B. and Efiong, J. (2010). Morphometric Parameters of the Calabar River Basin: Implication for Hydrologic Processes. Jour. Geogr. Geol., v.2 (1), pp.18-26.

Faniran (1968). The index of drainage intensity - A provisional new drainage factor, Australian Journal of Science, Vol.31, pp.328-330.

Gardiner, V. (1978). Redundancy and spatial organization of drainage basin form indices , Transactions of the Institute of British Geographers, New Series 3: 416-431.

Gravelius, H. (1914), Flusskunde, Goschensche Verlagshandlung, Berlin.

Gregory, K. J. (1978). Fluvial Processes in British Basins, in: C. Embleton, D, Brunsden and D.K.C. Jones (ed) Geomorphology- present problems and future prospects. OUP, NY, pp 40-72.

Guarnieri, P., Pirrotta, C. (2008). The response of drainage basins to the late quaternary tectonic in the Sicillian side of the Messina Strait (NE Sicily), Geomorphology, 95, pp. 260-273.

Hack, J. T. (1957). Studies of longitudinal stream profiles in Virginia and Maryland. U.S. Cool. Survey Prof. Paper 294-B, B45-897.

Horton, R. E. (1932). Drainage-basin characteristics. Transactions, American Geophysical Union, 13, 350-361.

Horton, R. E. (1945). Erosional Development of Streams and their Drainage Basins , Bulletin of the Geological Society of America, 56, pp-275-370.

Howard, A. D. (1967). Drainage analysis in geologic interpretation: a summation . AAPG Bull 51:2246-2259. 
Javed, A., Khanday, M. Y. and Rais, S., (2011). Watershed prioritization using morphometric and Land Use/Land Cover Parameters: A Remote Sensing and GIS Based Approach . Journal of Geological Society of India. 78: 63. https://doi.org/10.1007/ s12594-011-0068-6.

Javed, A., Khanday, M. Y. and Ahmed, R., (2009). Prioritization of Sub-Watersheds Based on Morphometric and Land Use Analysis Using Remote Sensing and GIS Techniques . Journal of the Indian Society of Remote Sensing. 37: 261. https://doi.org/ 10.1007/s12524-009-0016-8.

Khanday, M. Y. \& Javed, A. (2016). Prioritization of Sub-Watersheds for Conservation Measures in a Semi-Arid Watershed using Remote Sensing and GIS . Journal of Geological Society of India. Vol. 88 (2), pp. 185-196.

Leopold, L. B. \& Maddock, T. J. (1953). Hydraulic geometry of stream channels and some physiographic implications, U.S. Geol. Surv. Prof. Pap., 252, 55 pp., 1953.

Magesh, N. S., Chandrasekar, N. and Soundranayagam, J. P. (2011). Morphometric Evaluation of Papanasam and Manimuthar Watersheds: Parts of Western Ghats, Tirunelveli district, Tamil Nadu, India: a GIS approach , 64: 373 - 381

Melton, M. A. (1957). An analysis of the relations among elements of climate, surface properties and geomorphology (Project NR 389042, Tech. Rep. 11). New York, NY: Columbia University

Miller, V.C. (1953). A Quantitative geomorphic study of drainage basin characteristics on the Clinch Mountain area, Virgina and Tennessee, Proj. NR 389-402, Tech Rep 3, Columbia University, Department of Geology, ONR, New York.

Mueller, J. E. (1968). An introduction to the hydraulic and topographic sinuosity indexes 1 . Annals of the Association of American Geographers, 58, 371-385

Muthukrishnan, Manoj, K. S. \& Banu, K. K., (2013). Drainage Morphometry Evaluation for Kodavanar sub basin to understand the Interrelationships in Morphological Systems and in Process-Response Systems , International journal of Geon

Nautiyal, M. D. (1994). Morphometric Analysis of a Drainage Basin, Dist. Dehradun, Uttar Pradesh . J. Indian Soc. Remote Sensing, 22(4): 251-261.

Obi, G. P., Reddy, G. P., Maji, A. K., Gajbhiye, K. S., (2002). GIS for morphometric analysis of drainage basins , Geological Survey of India, 11, pp 9-14. 2002

Pandey, A., Chowdary, V. M. and Mal, B. C. (2004). Morphological analysis and watershed management using GIS , Hydrology J. 27, (3 \& 4), 71-84.

Pareta, K. (2011). Geo-Environmental and Geo-Hydrological Study of Rajghat Dam, Sagar (Madhya Pradesh) using Remote Sensing Techniques , International Journal of Scientific \& Engineering Research, 2(8) (ISSN 2229-5518), pp 1-8.

Patton, P. C. \& Baker, V. R. (1976). Morphometry and Floods in Small Drainage Basins , 12: 941-952

Perucca, L. P. \& Angilieri, Y. E. (2010). Morphometric characterization of del Molle Basin applied to the evaluation of flash floods hazard, Iglesia Department, San Juan, Argentina. Quaternary Internat., doi:10.1016/j.quaint.2010.08.007.

Prakash, K., Rawat, D., Singh, S. et al. (2019). Morphometric analysis using SRTM and GIS in synergy with depiction: a case study of the Karmanasa River basin, North central India, Appl Water Sci.9: 13. https://doi.org/10.1007/s13201-018-0887-3.

Pande, C., Moharir, K., \& Pande, R., (2018). Assessment of morphometric and hypsometric 
Rai, P.K. \& Singh, P. et al.: Geospatial approach for quantitative drainage morphometric analysis of Varuna river basin, India

study for watershed development using spatial technology - a case study of Wardha river basin in Maharashtra, India, International Journal of RIver Basin Management, https://doi.org/10.1080/15715124.2018.1505737.

Rai, P. K., Chandel, R. C., Mishra, V. N. and Singh, P. (2018). Hydrological Inferences through Morphometric Analysis of Lower Kosi River Basin of India for Water Resource Management based on Remote Sensing Data , Applied Water Science (Springer), 8-15, pp. 1-16. .DOI: https://doi.org/10.1007/s13201-018-0660-7.

Rai, P. K., Chaubey, P. K., Mohan, K. \& Singh, P. (2017b). Geoinformatics for assessing the inferences of quantitative drainage morphometry of the Narmada Basin in India, Applied Geomatics (Springer), Vol. 9 (3), 1-23. DOI:10.1007/s12518-017-0191-1

Rai, P. K., Mohan, K., Mishra, S., Ahmad, A. and Mishra, V. N., (2017). A GIS-based approach in drainage morphometric analysis of Kanhar River Basin, India . Applied Water Science, pp.1-16.

Rai, P.K., Mishra, V.N. \& Mohan, K. (2017a). A Study of Morphometric Evaluation of the Son Basin, India Using Geospatial Approach , Remote Sensing Applications: Society and Environment, Vol. 7, 9-20. DOI: 10.1016/j.rsase.2017.05.001.

Rais, S. \& Javed, A. (2014). Drainage Characteristics of Manchi Basin, Karauli District, Eastern Rajasthan Using Remote Sensing and GIS Techniques . International Journal of Geomatics and Geoscience, Vol. 5 (1), pp. 285-299.

Scheidegger, A. E. (1968). Horton's law of stream order numbers and a temperature-analog in river nets, Water Resour. Res., 4(1), 167-171, doi:10.1029/WR004i001p00167

Schumm, S. A. (1956). Evolution of Drainage Systems \& Slopes in Badlands at Perth An boy, New Jersey, Bulletin of the Geological Society of America, 67, pp 597-646.22.

Sharma, S. K., Gajbhiye, S., Nema, R. K., Tignath, S. (2015). Assessing vulnerability to soil erosion of a watershed of Narmada basin using remote sensing and GIS . Int J Sci Innov Eng Technol, issue 1, ISBN 978-81-904760-6-5

Singh, K. N. (1980). Quantitative analysis of landforms and settlement distribution in southern uplands of eastern Uttar Pradesh (India) .

Singh, P., Thakur, J. \& Singh U. C. (2013). Morphometric analysis of Morar River Basin, Madhya Pradesh, India, using remote sensing and GIS techniques. Environ Earth Sci 68:1967-1977

Singh, S., \& Dubey, A. (1994). Geo-environmental planning of watersheds in India. Allahabad: Chugh Publications.

Sinha, R. and Jain, V. (1998). Flood Hazards of North Bihar Rivers, Indo-Gangetic Plains. Mem. Geol. Soc. India, no.41, pp.27-52.

Smart, J. S. \& Surkan, A. J. (1967). The relation between mainstream length and area in drainage basins. Water Resources Research, 3, 963-973

Smith, K. G. (1950). Standards for grading texture of erosional topography. Am J Sci 248:655-668

Sreedevi, P. D., Srinivasal U. S. and Kesava Raju, K. (2001). Hydrogeomorphological and groundwater prospects of the Pageru River basin by using remote sensing data. Environ Geo 1, 40(8), pp10881094.

Sreedevi, P. D., Subrahmanyam, K. and Ahmed, S. (2005). The significance of morphometric analysis for obtaining groundwater potential zones in a structurally controlled 
terrain. Environ. Geol., v.47, pp.412-420.

Strahler, A. N. (1956). Quantitative Slope Analysis , Bulletin of the Geological Society of America, 67, pp 571.

Verstappen, H. (1983). The Applied Geomorphology. International Institute for Aerial Survey and Earth Science (I.T.C), Enschede, The Netherlands. Amsterdam, Oxford, New York.

Vinoth Kumar, R., Arun Venkatesh, S., Janapriya, S., Rajasekar, M. \& Muthuchamy, I. (2016). Morphometric analysis and prioritization of palathodi watershed in Parambikulam-Aliyar basin, Tamil Nadu using RS and GIS." Asian Journal of Environmental Science 11, no. 1 (2016): 51-58. 